\title{
MOLSIDOMINE INHIBITS THE CHEMOATTRACTANT- INDUCED RESPIRATORY BURST IN HUMAN NEUTROPHILS VIA A NO-INDEPENDENT MECHANISM
}

\author{
JÜRGEN ERVENS and ROLAND SEIFERT* \\ Institut für Pharmakologie, Freie Universität Berlin, Thielallee 69/73, D-1000 Berlin 33, Germany
}

(Received 5 August 1991; accepted 5 June 1992)

\begin{abstract}
Morpholino-sydnonimine (SIN-1) is a NO-rclcasing compound which mimics the effects of cGMP through activation of soluble guanylyl cyclase. Its prodrug, molsidomine (SIN-10), does not release NO but does modulate various cell functions. These findings prompted us to study the effects of SIN-10 and SIN-1 on the respiratory burst in human neutrophils. SIN-10 was more effective than SIN-1 in inhibiting superoxide anion $\left(\mathrm{O}_{2}^{-}\right)$formation induced by $N$-formyl-L-methionyl-L-leucyl-Lphenylalanine (fMet-Leu-Phe) and by C5a. The effects of SIN-1 and SIN-10 on $\mathrm{O}_{2}^{-}$formation were additive or less than additive, indicating the sydnonimines acted through a common mechanism. The sydnonimines showed no effect on $\mathrm{O}_{2}^{-}$formations induced by $\gamma$-hexachlorocyclohexane, arachidonic acid and a phorbol ester. They did not inhibit $\mathrm{O}_{2}^{-}$formation induced by xanthine oxidase, by autoxidation of pyrogallol and in a cell-free system from HL-60 leukemic cells. Neutrophils did not convert SIN-10 to SIN-1 as assessed by $\mathrm{O}_{2}$ consumption which accompanies NO relcase from SIN-1. The cell-permeant analogue of cGMP, $N^{2}, 2^{\prime}$-O-dibutyryl guanosine $3^{\prime}: 5^{\prime}$-monophosphate $\left(\mathrm{Bt}_{2} \mathrm{cGMP}\right)$, and SIN-10 but not SIN-1 inhibited fMet-Leu-Phe-induced $\mathrm{O}_{2}$ consumption. SIN-1 and SIN-10 slightly enhanced agonist binding to formyl peptide receptors, whereas $\mathrm{Bt}_{2} \mathrm{cGMP}$ was inhibitory. The sydnonimines did not affect GTP hydrolysis of heterotrimeric regulatory guanine nucleotide-binding proteins in HL-60 membranes. SIN-1 but not SIN-10 stimulated ADP-ribosylation of a 39-kDa protein in the cytosol of HL-60 cells. SIN-10 reduced fMet-Leu-Phe-induced rises in cytosolic $\mathrm{Ca}^{2+}$ concentration in neutrophils. These data suggest that SIN-10 inhibits the respiratory burst via a NO-independent mechanism which may involve inhibition of rises in cytosolic $\mathrm{Ca}^{2+}$ concentration.
\end{abstract}

In human neutrophils, the chemoattractants, $N$ formyl-L-methionyl-L-leucyl-L-phenylalanine ( fMetLeu-Phe $\dagger$ ) and complement $\mathrm{CSa}$, induce $\beta$-glucuronidase release from azurophilic granules and a respiratory burst $[1-4]$. The latter process is catalysed by NADPH oxidase [EC 1.6.99.6] and is characterized by $\mathrm{O}_{2}$ consumption and superoxide anion $\left(\mathrm{O}_{2}^{-}\right)$formation [1-4]. Formyl peptide and $\mathrm{C} 5 \mathrm{a}$ receptors interact with heterotrimeric guanine nucleotide-binding proteins (G-proteins), resulting in the stimulation of phospholipase $\mathrm{C}$ with subsequent activation of protein kinase $\mathrm{C}$ and rises in cytosolic $\mathrm{Ca}^{2+}$ concentration $\left(\left[\mathrm{Ca}^{2+}\right]_{\mathrm{i}}\right)[1,2,4]$. The mechanisms by which chemoattractants activate the respiratory burst are still a matter of debate and may involve activation of $\mathrm{G}$-proteins, low molecular mass GTP-binding proteins, protein kinase $\mathrm{C}$ and rises in $\left[\mathrm{Ca}^{2+}\right]_{i}[1,2,4]$.

* Corresponding author. Tel. (49) 30838 2064; FAX (49) 308315954.

† Abbreviations: $\mathrm{Bt}_{2} \mathrm{cAMP}, N^{6}, 2^{\prime}$-0-dibutyryl adenosine 3:5'-monophosphate; $\mathrm{Bt}_{2} \mathrm{CGMP}, N^{2}, 2^{\prime}$-0-dibutyryl guanosine $3^{\prime}: 5^{\prime}$-monophosphate; $\left[\mathrm{Ca}^{2+}\right]_{\mathrm{l}}$, cytosolic $\mathrm{Ca}^{2+}$ concentration; fMet-Leu-Phe, $N$-formyl-L-methionyl-L-leucylL-phenylalanine; G-protein, heterotrimeric regulatory guanine nucleotide-binding protein; $\mathrm{HCCH}, \gamma$-hexachlorocyclohexane; $\mathrm{O}_{2}^{-}$, superoxide anion; PMA, phorbol myristate acetate; SIN-1, 3-morpholino-sydnonimine; SIN10, molsidomine; SNP, sodium nitroprusside.
Recent data suggest that cGMP plays a role in the regulation of $\beta$-glucuronidase release and the respiratory burst, as its cell-permeant analogue, $N^{2}, 2^{\prime}$-O-dibutyryl guanosine $3^{\prime}: 5^{\prime}$-monophosphate $\left(\mathrm{Bt}_{2} \mathrm{cGMP}\right)$, inhibits enzyme release and $\mathrm{O}_{2}^{-}$ formation induced by fMet-Leu-Phe and potentiates those induced by C5a [5-7]. Neutrophils possess a cGMP-forming soluble guanylyl cyclase [8], a cGMPdependent protein kinase [9] and a cGMP-degrading phosphodiesterase [10]. Guanylyl cyclase is activated by the NO-releasing compounds, sodium nitroprusside (SNP) and 3-morpholino-sydnonimine (SIN-1) [11-13]. In agreement with the above data, SNP and SIN-1 increase cGMP levels in neutrophils [5]. Additionally, NO-releasing compounds activate ADP-ribosylation of a $39-\mathrm{kD}$ a protein and modulate various cell functions in a cGMP-independent manner [14-18]. Similar to other cell types, neutrophils generate NO [19-21], and NO-releasing compounds mimic, in part, the effects of $\mathrm{Bt}_{2} \mathrm{cGMP}$ on chemoattractant-induced $\beta$-glucuronidase release $[5,7]$.

SIN-10 is a prodrug and is converted to SIN-1 in the liver $[12,22]$. Accordingly, SIN-10 does not increase cGMP levels in neutrophils [5]. Surprisingly, SIN-10 inhibits $\beta$-glucuronidase release in neutrophils more effectively than SIN-1 $[5,7]$. Interestingly, an analogue of SIN-10 induces vasodilation, indicating that this substance does not only serve as a prodrug for a NO-releasing substance but is a 
pharmacologically active substance per se [23]. All these data prompted us to study the effects of SIN1 and SIN-10 on the respiratory burst in human neutrophils. We report here that SIN-10 inhibits the chemoattractant-induced respiratory burst via a NOindependent mechanism.

\section{MATERIALS AND METHODS}

Materials. SIN-1 and SIN-10 were kindly provided by Cassella (Frankfurt/Main, Germany). Stock solutions of SIN-1 $(100 \mathrm{mmol} / \mathrm{L})$ and SIN-10 $(50 \mathrm{mmol} / \mathrm{L})$ were prepared in 100 and $50 \mathrm{mmol} / \mathrm{L}$ Na-acetate, pH 5.0, immediately prior to use under light protection. Xanthine, xanthine oxidase [EC 1.2.3.2] (grade III, from buttermilk), superoxide dismutase (lyophilized powder, from bovine erythrocytes) [EC 1.15.1.1], ferricytochrome $c$ (type III, from horse heart), SNP, pyrogallol, antimycin, dithiothreitol and epinephrine were purchased from Sigma Chemie (Deisenhofen, Germany). The preparation of ferricytochrome $c$ used for the experiments in the present study contained up to $10 \%(\mathrm{w} / \mathrm{w})$ ferrocytochrome $c$. Stock solutions of SNP were prepared as described for SIN-1. Pyrogallol $(10 \mathrm{mmol} / \mathrm{L})$ was dissolved in $10 \mathrm{mmol} / \mathrm{L} \mathrm{HCl}$ immediately prior to use. Sources of other materials have been described elsewhere $[6,7,24-28]$.

Isolation of human neutrophils. Neutrophils were isolated from buffy coat obtained from the local blood bank or from individual healthy volunteers $[6,7,24]$. Cell preparations consisted of more than 95\% viable neutrophils as revealed by Trypan blue dye exclusion and Pappenheim-stained smears.

Cell culture. HL-60 cells were cultured in suspension culture as described $[24,25,27]$. HL- 60 cells were differentiated towards neutrophil-like cells upon incubation with $160 \mathrm{mmol} / \mathrm{L}$ dimethyl sulfoxide for $120 \mathrm{hr}$ or with $0.2 \mathrm{mmol} / \mathrm{L} \mathrm{Bt}{ }_{2}$ CAMP for $48 \mathrm{hr}$ $[24,25,27]$. HL-60 membranes and cytosol were prepared as described [25].

$\mathrm{O}_{2}^{-}$formation in intact human neutrophils. $\mathrm{O}_{2}^{-}$ formation was monitored at $550 \mathrm{~nm}$ by continuous measurement of ferricytochrome $c$ reduction inhibitable by superoxide dismutase [24]. Preliminary experiments revealed that SIN-1 and SIN-10 did not inhibit superoxide dismutase (data not shown). Reaction mixtures $(0.5 \mathrm{~mL})$ contained $100 \mu \mathrm{mol} / \mathrm{L}$ ferricytochrome $c$ and a buffer consisting of ( $\mathrm{mmol} /$ L) $138 \mathrm{NaCl}, 6 \mathrm{KCl}, 1 \mathrm{MgCl}_{2}, 1 \mathrm{CaCl}_{2}, 5.5$ glucose and 20 Hepes- $\mathrm{NaOH}, \mathrm{pH}$ 7.4. Neutrophils $\left(2.0 \times 10^{6}\right.$ cells) were suspended in the solution described above and were incubated for $3 \mathrm{~min}$ in the presence of various substances at $37^{\circ} . \mathrm{O}_{2}^{-}$formation was initiated by the addition of stimuli. In the experiments with fMet-Leu-Phe, C5a, HCCH and arachidonic acid, the absolute amounts of $\mathrm{O}_{2}^{-}$generated within an incubation period of $5 \mathrm{~min}$ were calculated. Within this time, $\mathrm{O}_{2}^{-}$formation ceased completely. In the experiments with phorbol myristate acetate (PMA), the maximum rate of $\mathrm{O}_{2}^{-}$formation, which was achieved within $5 \mathrm{~min}$ of addition of the stimulus, was calculated.

$\mathrm{O}_{2}^{-}$formation in a cell-free system from dimethyl sulfoxide-differentiated $H L-60$ cells. $\mathrm{O}_{2}^{-}$formation was monitored at $550 \mathrm{~nm}$ by continuous measurement of ferricytochrome $c$ reduction inhibitable by superoxide dismutase. Reaction mixtures $(0.5 \mathrm{~mL})$ contained $50 \mu \mathrm{g}$ membrane protein, $150 \mu \mathrm{g}$ cytosolic protein, $10 \mu \mathrm{mol} / \mathrm{L}$ FAD, $500 \mu \mathrm{mol} / \mathrm{L} \mathrm{NADPH}$, $100 \mu \mathrm{mol} / \mathrm{L}$ ferricytochrome $c, 2 \mathrm{mmol} / \mathrm{L} \mathrm{MgCl}_{2}$, $20 \mathrm{mmol} / \mathrm{L} \mathrm{KH}_{2} \mathrm{PO}_{4}, 40 \mathrm{mmol} / \mathrm{L} \mathrm{KCl}$ and $20 \mathrm{mmol} /$ $\mathrm{L}$ triethanolamine $/ \mathrm{HCl}, \mathrm{pH}$ 7.0. Reaction mixtures were incubated for $3 \mathrm{~min}$ at $25^{\circ}$ in the presence of various compounds. $\mathrm{O}_{2}^{-}$formation was initiated by the addition of arachidonic acid $(200 \mu \mathrm{mol} / \mathrm{L})$ [25]. The maximum rate of $\mathrm{O}_{2}^{-}$formation, which was achieved within $5 \mathrm{~min}$ of the addition of arachidonic acid, was calculated.

$\mathrm{O}_{2}^{-}$formation by xanthine oxidase. $\mathrm{O}_{2}^{-}$was generated by xanthine oxidase-catalysed conversion of xanthine to uric acid. $\mathrm{O}_{2}^{-}$formation was monitored at $550 \mathrm{~nm}$ by continuous measurement of ferricytochrome $c$ reduction inhibitable by superoxide dismutase [29]. Reaction mixtures $(0.5 \mathrm{~mL})$ contained xanthine $(50 \mu \mathrm{mol} / \mathrm{L})$, ferricytochrome $c$ $(100 \mu \mathrm{mol} / \mathrm{L})$ and a buffer composed of $50 \mathrm{mmol} / \mathrm{L}$ $\mathrm{KH}_{2} \mathrm{PO}_{4}$ and $0.1 \mathrm{mmol} / \mathrm{L}$ EDTA, $\mathrm{pH} 7.8$. Assays were conducted at $25^{\circ}$. Reactions were initiated by the addition of an amount of xanthine oxidase that induced the formation of $1.25 \mathrm{nmol}$ of $\mathrm{O}_{2}^{-} / \mathrm{min}$. $\mathrm{O}_{2}^{-}$formation was monitored for the first $3 \mathrm{~min}$ after addition of the enzyme.

$\mathrm{O}_{2}^{-}$formation by pyrogallol. $\mathrm{O}_{2}^{-}$was generated by autoxidation of pyrogallol [30]. $\mathrm{O}_{2}^{-}$formation was monitored at $550 \mathrm{~nm}$ by continuous measurement of ferricytochrome $c$ reduction inhibitable by superoxide dismutase under the conditions used for the determination of $\mathrm{O}_{2}^{-}$formation in intact neutrophils. Reaction mixtures were incubated for $3 \mathrm{~min}$ in the presence of various substances at $37^{\circ}$. $\mathrm{O}_{2}^{-}$formation was initiated by the addition of pyrogallol $(30 \mu \mathrm{mol} / \mathrm{L})$. Pyrogallol induced the formation of $3.5 \mathrm{nmol}$ of $\mathrm{O}_{2}^{-}$. Within $5 \mathrm{~min}, \mathrm{O}_{2}^{-}$ formation was terminated.

Effects of SIN-10 and SIN-1 on redox state of cytochrome $\mathrm{c}$. Under the experimental conditions used for measurement of $\mathrm{O}_{2}^{-}$formation in intact neutrophils, in a cell-free system from HL-60 cells, by xanthine oxidase and by pyrogallol, SIN-10 and SIN-1 up to $1 \mathrm{mmol} / \mathrm{L}$ per se did not induce $\mathrm{O}_{2}^{-}$ formation or oxidation of ferrocytochrome $c$ present in the commercial preparation. SIN-10 and SIN-1 $(0.1$ and $1 \mathrm{mmol} / \mathrm{L}$ each $)$ showed no oxidative effects on ferricytochrome $c$ reductions induced by dithiothreitol $(0.1 \mathrm{mmol} / \mathrm{L})$ or epinephrine $(1 \mathrm{mmol} /$ L), regardless of whether sydnonimines were added to reaction mixtures $3 \mathrm{~min}$ prior to or $3 \mathrm{~min}$ after the reducing substances. In addition, SIN-10 and SIN-1 ( 0.1 and $1 \mathrm{mmol} / \mathrm{L}$ each) did not induced reoxidation of cytochrome $c$ that was completely reduced by dithiothreitol or epinephrine.

$\mathrm{O}_{2}$ consumption in intact human neutrophils. $\mathrm{O}_{2}$ consumption was measured using a Biometer $\mathrm{O}_{2}$ electrode (Braun, Melsungen, Germany) according to the protocol described by Absolom [3]. Neutrophils $\left(3 \times 10^{7}\right.$ cells) were suspended at $37^{\circ}$ in $3 \mathrm{~mL}$ of the buffer used for the determination of $\mathrm{O}_{2}^{-}$formation in intact cells supplemented with antimycin $(10 \mu \mathrm{mol} /$ L) and cytochalasin B $(1 \mu \mathrm{g} / \mathrm{mL})$. Cells were stirred at $500 \mathrm{rpm} . \mathrm{O}_{2}$ consumption was measured in the presence of various compounds. 
fMet-Leu-Phe binding assay. fMet-Leu-Phe binding was performed as described [26]. Reaction mixtures $(100 \mu \mathrm{L})$ contained $40 \mu \mathrm{g}$ of membrane protein from $\mathrm{Bt}_{2} \mathrm{CAMP}$-differentiated HL-60 cells, bovine serum albumin $(0.2 \%, \mathrm{w} / \mathrm{v}), 50 \mathrm{mmol} / \mathrm{L}$ Tris-HCl, $\mathrm{pH} 7.3,1 \mathrm{mmol} / \mathrm{L}$ EDTA and $5 \mathrm{mmol} / \mathrm{L}$ $\mathrm{MgCl}_{2}$ in the presence of various substances. Incubations were conducted for $30 \mathrm{~min}$ at $25^{\circ}$ and were initiated by the addition of $3 \mathrm{nmol} / \mathrm{L}$ met-Leu- $\left[{ }^{3} \mathrm{H} \mid \mathrm{Phe}(17 \mathrm{nCl} /\right.$ tube), Reactions were terminated by the rapid filtration technique. Radioactivity on dried filters was determined in a liquid scintillation counter. Unspecific binding was determined in the presence of $10 \mu \mathrm{mol} / \mathrm{L}$ fMet-LeuPhe and amounted to less than $10 \%$ of total binding.

Measurement of GTPase activity. GTP hydrolysis was measured as described [27]. Assay mixtures $(100 \mu \mathrm{L})$ contained membranes from $\mathrm{Bt}_{2} \mathrm{CAMP}$. differentiated HL-60 cells $(7.0 \mathrm{~kg}$ of protein/tube), $0.5 \mu \mathrm{mol} / \mathrm{L}\left[\gamma^{32} \mathrm{P}\right] \mathrm{GTP}(0.1 \mu \mathrm{Cl} / \mathrm{tube}), 5 \mathrm{mmol} / \mathrm{L}$ $\mathrm{MgCl}_{2}, 0.1 \mathrm{mmol} / \mathrm{L}$ EGTA, $0.1 \mathrm{mmol} / \mathrm{L}$ ATP, $1 \mathrm{mmol} / \mathrm{L}$ adenosine $5^{\prime}$-[ $\beta, \gamma$-imido $]$-triphosphate, $5 \mathrm{mmol} / \mathrm{L}$ creatine phosphate, $40 \mu \mathrm{g}$ of creatine kinase, $1 \mathrm{mmol} / \mathrm{L}$ dithiothreitol and $0.2 \%(\mathrm{w} / \mathrm{v})$ bovine serum albumin in $50 \mathrm{mmol} / \mathrm{L}$ triethanolamine-HC, pH 7.4. Reaction mixtures contained various additional substances. Reactions were initiated by the addition of $\left[\gamma-{ }^{32} \mathrm{P}\right] \mathrm{GTP}$ and were conducted for $15 \mathrm{~min}$ at $25^{\circ}$. Low-affinity GTPase activity was determined in the presence of GTP $(50$ umol/L) and amounted to $<5 \%$ of total GTPase activity.

[?P]ADP-ribosylation of proteins in cytasol from HL 60 cells and gel electrophoresis. [ [22]ADPribosylation of cytosolic proteins from dimethyl sulfoxide-differentiated HL-60 cells was performed according to Dimmeler and Brüne [15]. Briefly, assay mixtures $(60 \mu \mathrm{L})$ contained $100 \mu \mathrm{g}$ of cytosolic proteins, $1 \mu \mathrm{mol} / \mathrm{L}\left[{ }^{32} \mathrm{P}\right] \mathrm{NAD}(2 \mu \mathrm{Ci} / \mathrm{tube}), 2 \mathrm{mmol} /$ $\mathrm{L}$ dithiothreitol and $0.2 \%(\mathrm{w} / \mathrm{v})$ bovine serum albumin in $50 \mathrm{mmol} / \mathrm{L}$ Hepes-NaOH, pH7.5. Assays contained various additional substances. Incubations were conducted for $45 \mathrm{~min}$ at $37^{\circ}$. Thereafter, proteins were precipitated by acetone. Precipitates were washed with trichloracetic acid and subsequently with methanol-chloroform $(1: 2, v / v)$. Proteins were resolved by SDS-PAGE on geis containing $12.5 \%(\mathrm{w} / \mathrm{v})$ acrylamide. Staining of dried gels with Coomassie blue and autoradiography were performed as described [28].

Measurement of $\left[\mathrm{Ca}^{2+}\right]_{i} \cdot\left[\mathrm{Ca}^{2+}\right]_{i}$ was determined using the fluorescent dye, Fura-2, as described $[7,26]$. Neutrophils were suspended at $5 \times 10^{6}$ cells $\mathrm{mL}$ in a buffer consisting of (mmol/L) $138 \mathrm{NaCl}, 6$ $\mathrm{KCl}, 1 \mathrm{MgSO}_{4}, 1.1 \mathrm{CaCl}_{2}$, 0.1 EGTA, $1 \mathrm{Na}_{2} \mathrm{HPO}_{4}$, $5 \mathrm{NaHCO}_{3}, 5.5$ glucose, 20 Hepes- $\mathrm{NaOH}, \mathrm{pH} 7.4$, supplemented with bovine serum albumin $(0.1 \%$, (w/v). Cells were incubated for $1 \mathrm{hr}$ at $37^{\circ}$ in the presence of Fura-2-acetoxymethylester $(4 \mu \mathrm{mol} / \mathrm{L})$. Subsequenily, cells were diluted with the above buffer to a final concentration of $0.5 \times 10^{6}$ cells $/ \mathrm{mL}$ and were centrifuged for $10 \mathrm{~min}$ at $250 \mathrm{~g}$ at $20^{\circ}$. Celis were suspended at $1.0 \times 10^{6}$ cells $/ \mathrm{mL}$ in the above buffer and were kept at $20^{\circ}$ until measurement of

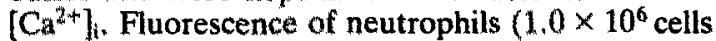
in $2 \mathrm{~mL}$ ) was determined at $37^{\circ}$ under constant stirring at $10^{3}$ rpm using a Ratio II spectrofluorometer (Aminco, Silver Spring, MD, U.S.A.). Cells were incubated for $3 \mathrm{~min}$ in the presence of SIN-10 or solvent prior to the addition of Met-Leu-Phe. The excitation and emission wavelengths were 340 and $500 \mathrm{~nm}$, respectively.

Miscellaneous. Protein was determined according to Lowry et al. [31]. [ $\left.\gamma^{32} \mathrm{P}\right] \mathrm{GTP}$ was synthesized according to Johnson and Walseth [32]. [ ${ }^{32}$ P]NAD was prepared as described [33]. The effects of sydnonimines were statistically assessed using the Wilcoxon test.

\section{RESULTS}

First, the effects of sydnonimines on $\mathrm{O}_{2}^{-}$formation in intact human neutrophils were studied. Sydnonimines were employed at concentrations ranging from $3 \mathrm{umol} / \mathrm{L}$ to $1 \mathrm{mmol} / \mathrm{L}$, i.e. concentrations commonly used in various systems $[5,7,12,14,18$, 22-34]. SIN-10 and SIN-1 inhibited fMet-Leu-Pheinduced $\mathrm{O}_{2}^{-}$formation in a concentration-dependent manner (Fig. 1). SIN-10 was considerably more effective than SIN-1. The solvent Nawacetate did not inhibit $\mathrm{O}_{2}^{-}$formation.

The interaction of sydnonimines with $\mathrm{Met}-\mathrm{Let}$ Phe-induced $\mathrm{O}_{2}^{-}$formation was studied (Fig. 2). SIN-1 (1 mmol/L $)$ enhanced additively the inhibitory effect of SIN-10 $(0.1 \mathrm{mmol} / \mathrm{L})$ on $\mathrm{O}_{2}^{-}$formation. However, under various other conditions, the inhibitory effects of SIN-1 and SIN-10 were not additive.

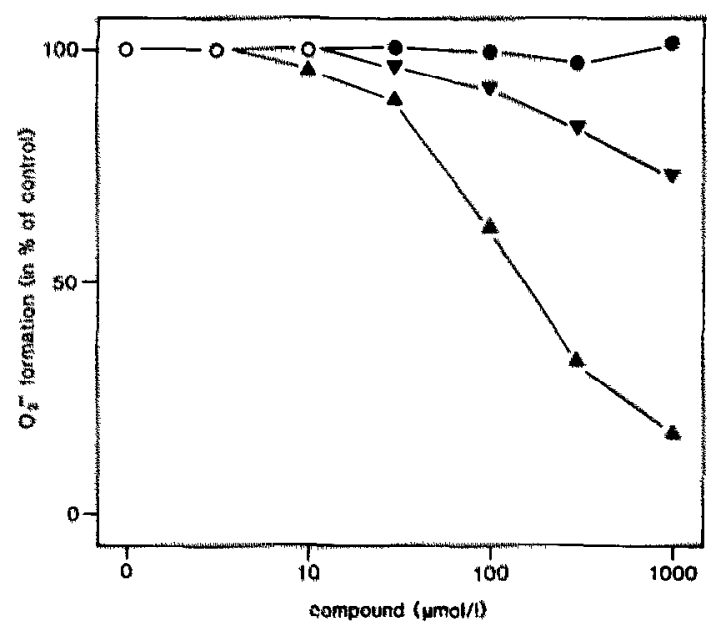

Fig. 1. Concentration dependency of the effects of SIN. 10, SIN-1 and Na-acetate on PMet-Leu-Phe-induced $\mathrm{O}_{2}^{-}$ formation in human neutrophis. Compounds at the indicated concentrations were added to reaction mixtures 3 min prior to fMet.t.Leu-Phe $(1 \mu \mathrm{mol} / \mathrm{L})$. In the presence of $\mathrm{H}_{2} \mathrm{O}$ (control), fMet-Leu-Phe induced the formation of $\$ .1 \pm 0.3 \mathrm{nmol}$ of $\mathrm{O}_{2} / 10^{6}$ cells. Data shown are referred to these values and are the means of five independent experiments; the SD values of the data were generally $<15 \%$ of the means. The open circles indicate that substances at the indicated concentrations did not inhibit $\mathrm{O}_{\overline{4}}$ formation. (A) SIN-10; (V) SIN-1; (O) Na-acetate. The inhibitory effects of SIN-10 and SIN-1 on $\mathrm{O}_{2}^{-}$formation versus control were significant at $0.1,0.3$ and $1 \mathrm{mmol} / \mathrm{L}$ and at 0.3 and $1 \mathrm{mmol} / \mathrm{L}$, respectively $(P<0.05$ or $P<0.01$ ) 


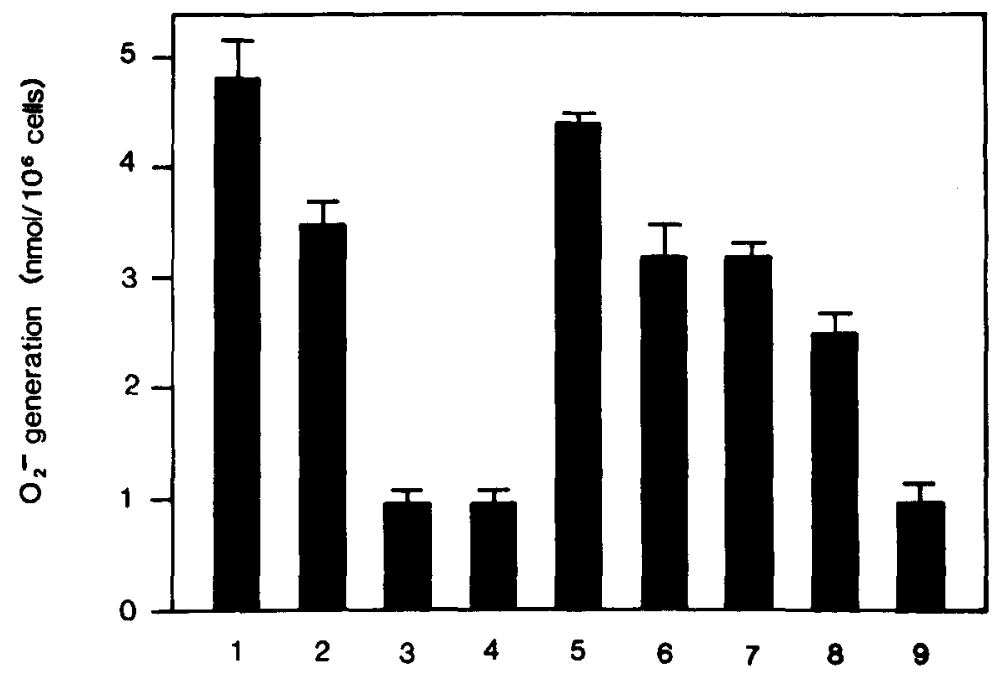

Fig. 2. Interaction of SIN-10 and SIN-1 on fMet-Leu-Phe-induced $\mathrm{O}_{2}^{-}$formation in human neutrophils. Compounds at various concentrations were added to reaction mixtures 3 min prior to fMet-Leu-Phe $(1 \mu \mathrm{mol} / \mathrm{L}) .1$, solvent (control); 2 , SIN-1 $(1 \mathrm{mmol} / \mathrm{L}) ; 3$, SIN-10 $(1 \mathrm{mmol} / \mathrm{L}) ; 4$, SIN-1 plus SIN-10 $(1 \mathrm{mmol} / \mathrm{L}$ each $) ; 5$, SIN-1 $(0.1 \mathrm{mmol} / \mathrm{L}) ; 6$, SIN-10 $(0.1 \mathrm{mmol} / \mathrm{L}) ; 7, \mathrm{SIN}-1 \mathrm{plus}$ SIN-10 $(0.1 \mathrm{mmol} / \mathrm{L}$ each); $8, \operatorname{SIN}-1(1 \mathrm{mmol} / \mathrm{L})$ plus SIN-10 $(0.1 \mathrm{mmol} / \mathrm{L}) ; 9, \mathrm{SIN}-1(0.1 \mathrm{mmol} / \mathrm{L})$ plus $\mathrm{SIN}-10(1 \mathrm{mmol} /$

L). Data shown are the means $\pm \mathrm{SD}$ of four independent experiments.

Table 1 compares the effects of SIN-10 and SIN1 on $\mathrm{O}_{2}^{-}$formation in neutrophils induced by various stimuli. In the presence of fMet-Leu-Phe at a submaximally effective concentration, SIN-10 and SIN-1 inhibited $\mathrm{O}_{2}^{-}$formation to similar extents as did fMet-Leu-Phe at a maximally effective concentration. By analogy to fMet-Leu-Phe, SIN-10 was more effective than SIN-1 in inhibiting C5a-induced $\mathrm{O}_{2}^{-}$formation. In contrast, SIN-10 and SIN-1 did not affect $\mathrm{O}_{2}^{-}$formation induced by $\mathrm{HCCH}$, arachidonic acid and PMA, i.e. stimuli which circumvent receptor stimulation.

In a cell-free system from HL-60 cells, arachidonic acid induced the formation of $\mathrm{O}_{2}^{-}$at a rate of $20 \mathrm{nmol}$ of $\mathrm{O}_{2}^{-} / \mathrm{min} / \mathrm{mg}$ of membrane protein. Guanosine $5^{\prime}$ $O$-(3-thiotriphosphate) $(10 \mu \mathrm{mol} / \mathrm{L})$, an activator of G-proteins and low molecular mass GTP-binding proteins [2], enhanced this $\mathrm{O}_{2}^{-}$formation by about 3.5-fold (data not shown) [25]. SIN-10 and SIN-1 $\left(1 \mathrm{mmol} / \mathrm{L}\right.$ each) did not inhibit $\mathrm{O}_{2}^{-}$formation in this system (data not shown).

Radical scavenging may explain inhibition by NO of NADPH oxidase-catalysed $\mathrm{O}_{2}^{-}$formation [35]. Therefore, the effects of SIN-10 and SIN-1 on $\mathrm{O}_{2}^{-}$ formation in systems unrelated to NADPH oxidase were assessed. SIN-10 and SIN-1 $(1 \mathrm{mmol} / \mathrm{L}$ each $)$

Table 1. Effects of SIN-10 and SIN-1 on $\mathrm{O}_{2}^{-}$formation in human neutrophils induced by various stimuli

\begin{tabular}{lcc}
\hline & \multicolumn{2}{c}{$\mathrm{O}_{2}^{-}$formation $(\%$ of control) } \\
\cline { 2 - 3 } \multicolumn{1}{c}{ Stimulus } & SIN-10 & SIN-1 \\
\hline fMet-Leu-Phe $(20 \mathrm{nmol} / \mathrm{L})$ & $13 \dagger$ & $60 \dagger \S$ \\
fMet-Leu-Phe $(1 \mu \mathrm{mol} / \mathrm{L})$ & $20 \dagger$ & $73+\S$ \\
C5a $(10 \mathrm{nmol} / \mathrm{L})$ & $34^{\dagger}$ & $77 \dagger \S$ \\
HCCH $(125 \mu \mathrm{mol} / \mathrm{L})$ & $105^{*}$ & $96^{*} \ddagger$ \\
Arachidonic acid $(20 \mu \mathrm{mol} / \mathrm{L})$ & $97^{*}$ & $95^{*} \ddagger$ \\
PMA $(100 \mathrm{ng} / \mathrm{mL})$ & $98^{*}$ & $97^{*} \ddagger$ \\
\hline
\end{tabular}

SIN-10 or SIN-1 (1 mmol/L each) or solvent (control) was added to reaction mixtures 3 min prior to stimuli. Data shown are referred to $\mathrm{O}_{2}^{-}$formations induced by substances in the presence of solvent and are the means of six independent experiments; the SD values of the data were generally $<15 \%$ of the means. In the presence of solvent, $\mathrm{Met}-\mathrm{Leu}-\mathrm{Phe}(20 \mathrm{nmol} / \mathrm{L})$ and $(1 \mu \mathrm{mol} /$ $\mathrm{L})$ induced the formation of $1.7 \pm 0.3$ and $5.3 \pm 0.4 \mathrm{nmol}$ of $\mathrm{O}_{2}^{-} / 10^{6}$ cells, respectively. The corresponding values for $\mathrm{C} 5 \mathrm{a}, \mathrm{HCCH}$ and arachidonic acid were $1.3 \pm 0.1,1.8 \pm 0.2$ and $1.9 \pm 0.2 \mathrm{nmol}$ of $\mathrm{O}_{2}^{-} / 10^{6}$ cells, respectively. PMA induced the formation of $10.5 \pm 0.2 \mathrm{nmol}$ of $\mathrm{O}_{2}^{-} / \mathrm{min} / 10^{6}$ cells. Comparison of the effects of compounds versus control: * not significant; $\uparrow P<0.01$. Comparison of the effects of SIN-10 versus SIN-1: $\ddagger$ not significant; $\S P<0.01$. 


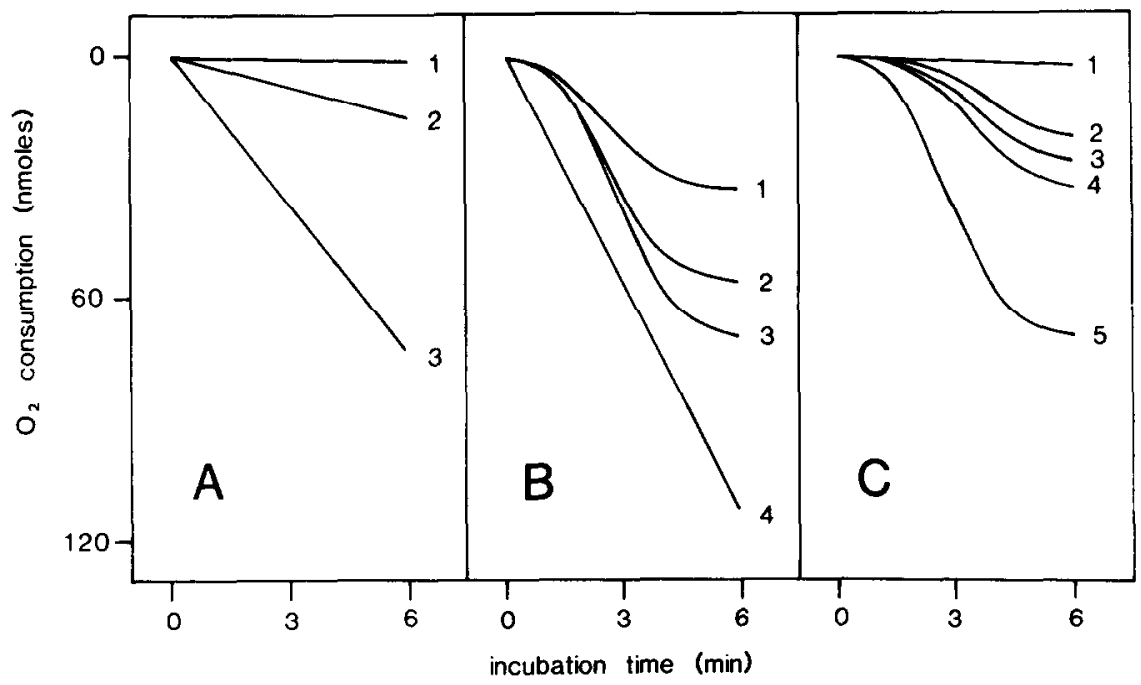

Fig. 3. Effects of SIN-10, SIN-1, $\mathrm{Bt}_{2} \mathrm{cAMP}$ and $\mathrm{Bt}_{2} \mathrm{cGMP}$ on $\mathrm{O}_{2}$ consumption in human neutrophils. $\mathrm{O}_{2}$ consumption was measured at $37^{\circ}$ using an $\mathrm{O}_{2}$ electrode. Assays contained $3 \times 10^{7}$ neutrophils each. In the experiments shown in panel $\mathrm{A}$, sydnonimines were added to cells at $t=0 \mathrm{~min}$. In the experiments shown in panels $B$ and $C$, fMet-Leu-Phe was added to cells at $t=0 \mathrm{~min}$; sydnonimines, $\mathrm{Bt}_{2} \mathrm{CAMP}$, $\mathrm{Bt}_{2} \mathrm{cGMP}$ or solvent (control) was added to reaction mixtures 3 min prior to fMet-Leu-Phe. Panel A: trace $1, \operatorname{SIN}-10(1 \mathrm{mmol} / \mathrm{L})$; trace $2, \operatorname{SIN}-1(0.1 \mathrm{mmol} / \mathrm{L})$; trace $3, \operatorname{SIN}-1(1 \mathrm{mmol} / \mathrm{L})$. Panel B: trace 1 , fMet-Leu-Phe $(50 \mathrm{nmol} / \mathrm{L})$ plus solvent (control) or fMet-Leu-Phe $(1 \mu \mathrm{mol} / \mathrm{L})$ plus SIN-10 $(1 \mathrm{mmol} /$ L); trace 2, fMet-Leu-Phe $(1 \mu \mathrm{mol} / \mathrm{L})$ plus SIN-10 $(0.3 \mathrm{mmol} / \mathrm{L})$; trace 3 , fMet-leu-Phe $(1 \mu \mathrm{mol} / \mathrm{L})$ plus solvent (control) or SIN-10 $(0.1 \mathrm{mmol} / \mathrm{L})$; trace 4 , fMet-Leu-Phe $(50 \mathrm{nmol} / \mathrm{L})$ plus SIN-1 $(1 \mathrm{mmol} / \mathrm{L})$. Panel C: trace 1 , fMet-Leu-Phe $(50 \mathrm{nmol} / \mathrm{L})$ plus $\mathrm{Bt}_{2} \mathrm{CGMP}(1 \mathrm{mmol} / \mathrm{L})$; trace 2 , fMet-Leu-Phe $(50 \mathrm{nmol} / \mathrm{L})$ plus Bt ${ }_{2} \mathrm{CAMP}(1 \mathrm{mmol} / \mathrm{L})$; trace 3 , fMet-Leu-Phe $(1 \mu \mathrm{mol} / \mathrm{l}) \mathrm{plus} \mathrm{Bt}{ }_{2} \mathrm{cAMP}(1 \mathrm{mmol} / \mathrm{L})$; trace 4, fMet-Leu-Phe $(50 \mathrm{nmol} / \mathrm{L})$ plus solvent (control); trace 5 , fMet-Leu-Phe $(1 \mu \mathrm{mol} / \mathrm{L})$ plus solvent (control) or $\mathrm{Bt}_{2} \mathrm{cGMP}(1 \mathrm{mmol} / \mathrm{L})$. Superimposed original tracings from one experiment are shown. Similar results were obtained in five independent experiments.

showed no effect on xanthine oxidase-catalysed $\mathrm{O}_{2}^{-}$formation (data not shown). Additionally, sydnonimines $(1 \mathrm{mmol} / \mathrm{L}$ each) did not inhibit pyrogallol-induced $\mathrm{O}_{2}^{-}$formation (data not shown).

Release of NO from SIN-1 is associated with $\mathrm{O}_{2}$ consumption [22]. In order to answer the question as to whether neutrophils convert SIN-10 to SIN-1, $\mathrm{O}_{2}$ consumption in the presence of sydnonimines and cells was studied. SIN-10 did not induce $\mathrm{O}_{2}$ consumption (Fig. 3). By contrast, SIN-1 (0.1 and $1 \mathrm{mmol} / \mathrm{L}$ ) induced substantial $\mathrm{O}_{2}$ consumption. SIN-10 $(0.3$ and $1 \mathrm{mmol} / \mathrm{L})$ significantly inhibited fMet-Leu-Phe-induced $\mathrm{O}_{2}$ consumption (see Fig. 3). Similar to $\mathrm{O}_{2}^{-}$formation, SIN-10 did not inhibit $\mathrm{O}_{2}$ consumption induced by PMA $(100 \mathrm{ng} / \mathrm{mL}$ ) (see Table 1, data not shown). SIN-1 enhanced fMetLeu-Phe-induced $\mathrm{O}_{2}$ consumption in an additive manner. For comparison with sydnonimines, the effects of $N^{6}, 2^{\prime}$-O-dibutyryl adenosine 3:5' -cyclic monophosphate ( $\left.\mathrm{Bt}_{2} \mathrm{CAMP}\right)$ and $\mathrm{Bt}_{2} \mathrm{CGMP}$ on fMetLeu-Phe-induced $\mathrm{O}_{2}$ consumption were studied (see Fig. 3). As was the case for $\mathrm{O}_{2}^{-}$formation [6], $\mathrm{Bt}_{2} \mathrm{CGMP}$ was more effective than $\mathrm{Bt}_{2} \mathrm{CAMP}$ in inhibiting $\mathrm{O}_{2}$ consumption stimulated by fMet-LeuPhe at a submaximally effective concentration. $\mathrm{Bt}_{2}$ cAMP but not $\mathrm{Bt}_{2} \mathrm{cGMP}$ inhibited $\mathrm{O}_{2}$ consumption induced by fMet-Leu-Phe at a maximally effective concentration.

In order to study the mechanism by which sydnonimines inhibit the chemoattractant-induced respiratory burst, their effects on agonist binding to formyl peptide receptors and on high-affinity GTPase activity of G-proteins in HL-60 membranes were studied (Table 2). Sydnonimines enhanced agonist binding by up to $17 \%$, whereas Bt2cGMP inhibited fMet-Leu-Phe binding by $32 \% . \mathrm{Bt}_{2}$ cAMP was less inhibitory than $\mathrm{Bt}_{2} \mathrm{cGMP}$. None of the above substances showed an effect on high-affinity GTP hydrolysis (see Table 2).

The effects of sydnonimines and of SNP on ADPribosylation of a $39-\mathrm{kDa}$ protein in the cytosol of HL-60 cells are shown in Fig. 4. In agreement with the results of a recent study, we found that SNP stimulates ADP-ribosylation of the 39-kDa substrate in the cytosol of these cells [15]. SIN-1 was more effective than SNP in inducing ADP-ribosylation of this protein. In comparison, SIN-10 induced little, if any ADP-ribosylation of the $39-\mathrm{kDa}$ protein.

Finally, the effects of SIN-10 on $\left[\mathrm{Ca}^{2+}\right]_{i}$ were studied. SIN-10 $(10 \mu \mathrm{mol} / \mathrm{L})$ did not affect basal $\left[\mathrm{Ca}^{2+}\right]_{\mathrm{i}}$ in human neutrophils (Table 3). However, the sydnonimine inhibited rises in $\left[\mathrm{Ca}^{2+}\right]_{i}$ induced by fMet-Leu-Phe at a submaximally and maximally effective concentration by more than $30 \%$. Unfortunately, the effects of SIN-10 at higher concentrations on $\left[\mathrm{Ca}^{2+}\right]_{i}$ could not be quantitatively assessed as the sydnonimine quenched basal fluorescence signals (data not shown). 
Table 2. Effects of SIN-10, SIN-1, Bt ${ }_{2} \mathrm{cAMP}$ and $\mathrm{Bt}_{2} \mathrm{cGMP}$ on agonist binding to formyl peptide receptors and on high-affinity GTPase activity in HL-60 membranes

\begin{tabular}{lcc}
\hline \multicolumn{1}{c}{ Addition } & $\begin{array}{c}\text { Met-Leu-Phe binding } \\
\text { (mol/mg protein) }\end{array}$ & $\begin{array}{c}\text { GTP hydrolysis } \\
(\text { pmol } \mathbf{P} / \mathrm{mg} / \mathrm{min})\end{array}$ \\
\hline Solvent (control) & $598 \pm 23$ & $25.6 \pm 0.8$ \\
SIN-10 $(1 \mathrm{mmol} / \mathrm{L})$ & $676 \pm 38 \dagger$ & $25.9 \pm 0.3^{*}$ \\
$\mathrm{SIN}-1(1 \mathrm{mmol} / \mathrm{L})$ & $700 \pm 42 \dagger$ & $26.1 \pm 1.0^{*}$ \\
$\mathrm{Bt}_{2} \mathrm{cAMP}(1 \mathrm{mmol} / \mathrm{L})$ & $520 \pm 18 \dagger$ & $25.5 \pm 0.9^{*}$ \\
$\mathrm{Bt}_{2} \mathrm{cGMP}(1 \mathrm{mmol} / \mathrm{L})$ & $407 \pm 19+$ & $24.8 \pm 1.1^{*}$ \\
\hline
\end{tabular}

Aet-Len-Phe binding to formyl peptide receptors and high-affinity GTPase activity of $\mathrm{G}$-proteins in membranes from $\mathrm{Bt}_{2} \mathrm{CAMP}$-differentiated $\mathrm{HL}-60$ cells were measured in the presence of various substances at the indicated concentrations or solvent (control) under the conditions described in Materials and Methods. Data shown are the means $\pm \mathrm{SD}$ of three experiments performed in quadruplicate each. Comparison of the effects of compounds versus control: ${ }^{*}$ not significant; $\dagger P<0.05 ; \neq P<0.01$.

\section{DISCUSSION}

SIN-10 is the prodrug of the NO-releasing substance, SIN $11[12,22]$. Somewhat unexpectedly, we found that SIN-10 very effectively inhibits the fMet-Leu-Phe-induced respiratory burst in human neutrophils (see Figs 1-3 and Table 1). In agreement with these data, $\mathrm{fMet}$-Leu-Phe-induced $\beta$. glucuronidase release is substantially inhibited by SIN-10 [5, 7]. The lack of synergism between SIN10 and SIN-1 in the inhibition of fMet-Leu-Pheinduced $\mathrm{O}_{2}^{-}$formation indicates that sydnonimines act through a common mechanism (see Fig. 2).

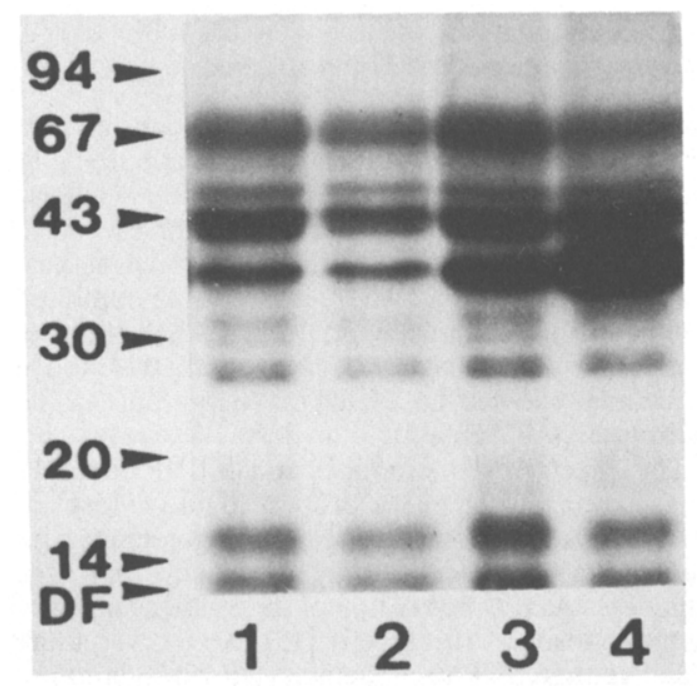

Fig. 4. Effects of SIN-10, SIN-1 and SNP on ADP. ribosylation of a $39-\mathrm{kDa}$ protein in cytosol from dimethyl sulfoxide-differentiated HL-60 cells. Cytosolic proteins from dimethyl sulfoxide-differentiated HL-60 cells $(100 \mu \mathrm{g} /$ fube) were incubated for $45 \mathrm{~min}$ in the presence of $\left[{ }^{32} \mathrm{p}\right]$ NAD and various substances. Proteins were analysed as described in Materials and Methods. The autoradiogram of a Coomassie blue-stained gel is shown. Lane $1, \mathrm{SN} \cdot 10$ $(1 \mathrm{mmol} / \mathrm{L})$; lane 2 , solvent (control); lane $3, \mathrm{SNP}(1 \mathrm{mmol} /$ L); lane $4, \operatorname{SIN}-1(1 \mathrm{mmol} / \mathrm{L})$. Numbers on the left represent molecular masses of marker proteins $(\mathrm{kDa}) ; \mathrm{DF}$, dye front. Similar results were obtained in three experiments.
Several data suggest that sydnonimines inhibit the respiratory burst through a mechanism which is independent of NO release with subsequent activation of soluble guanylyl cyclase and increase in cGMP. First, SIN-10 was considerably more effective than SIN-1 in inhibiting Pet-Leu-Pheinduced $\mathrm{O}_{2}^{-}$formation (see Figs 1 and 2). Second, SIN-10 substantially inhibited fMet-Leu-Phe-induced $\mathrm{O}_{2}$ consumption, whereas SIN-1 did not (see Fig. 3). Third, neutrophils did not convert SIN-10 to SIN-1, as the former substance did not induce $\mathrm{O}_{2}$ consumption, a process which accompanies the release of NO from SIN-1 (see Fig. 3) [22]. In agreement with these data is the finding that SIN10 does not increase cGMP levels in human neutrophils [5]. Additionally, SIN-10 did not mimic the effects of $\mathrm{Bt}_{2} \mathrm{cGMP}$ on the respiratory burst. Specifically, sydnonimines inhibited the effects of fMet-Leu-Phe at a submaximally and maximally effective concentration on the respiratory burst, whereas $\mathrm{Bt}_{2} \mathrm{cGMP}$ only inhibited $\mathrm{O}_{2}$ formation and $\mathrm{O}_{2}$ consumption induced by fMet-Leu-Phe at a submaximally effective concentration (see Figs 1-3 and Table 3) [6]. Finally, sydnonimines inhibited C5a-induced $\mathrm{O}_{2}^{-}$formation, whereas $\mathrm{Bt}_{2} \mathrm{cGMP}$ potentiated the effects of C5a (see Table 1) [6].

What may be the mechanism by which sydnonimines

Table 3. Effects of SIN-10 and SIN-1 on fMet-Leu-Phew induced rises in $\left[\mathrm{Ca}^{2+}\right]_{i}$ in human neutrophils

\begin{tabular}{llc}
\hline & \multicolumn{2}{c}{ Increase in $\left[\mathrm{Ca}^{2+}\right](\mathrm{nmol} / \mathrm{L})$} \\
\cline { 2 - 3 } \multicolumn{1}{c}{ Stimulus } & Control & (SIN-10) \\
\hline fMet-Leu-Phe $(1 \mathrm{nmol} / \mathrm{L})$ & $487 \pm 47$ & $326 \pm 50^{*}$ \\
fMet-Leu-Phe $(10 \mathrm{nmol} / \mathrm{L})$ & $955 \pm 32$ & $628 \pm 38^{*}$ \\
\hline
\end{tabular}

Cells were loaded with Fura-2 acetoxymethylester and the increases in $\left[\mathrm{Ca}^{2+}\right]_{\text {induced }}$ ind $\mathrm{Met}-\mathrm{Lew}$-Phe at the indicated concentrations were determined. STN-10 $(10 \mu \mathrm{mol} / \mathrm{L}$ ) or solvent (control) were added to reaction mixtures 3 min prior to fMet-Let -Phe. Basal $\left[\mathrm{Ca}^{2+}\right]_{i}$ in control and SIN-10-treated cells was $149 \pm 10 \mathrm{nmol} / \mathrm{L}$ and $145 \pm 5 \mathrm{nmol} / \mathrm{L}$, respectively, Data shown are the means \pm SD of five experiments. Comparison of the effects of SIN. 10 versus control: * $\mathrm{P}<0.05$. 
inhibit the chemoattractant-induced respiratory burst? Under the conditions employed, the sydnonimines did not interfere with the detection method for $\mathrm{O}_{2}^{-}$formation (see Materials and Methods). Additionally, these substances did not reoxidize ferrocytochrome $c$ (see Materials and Methods). Moreover, the sydnonimines did not scavenge $\mathrm{O}_{2}^{-}$as is supported by their lack of effect on xanthine oxidase-catalysed and pyrogallolinduced $\mathrm{O}_{2}^{-}$formation and on receptor-independent activation of $\mathrm{O}_{2}^{-}$formation in intact neutrophils and in a cell-free system from HL-60 cells (see Table 1). Furthermore, SIN-10 inhibited not only fMet-LeuPhe-induced $\mathrm{O}_{2}^{-}$formation, but also fMet-Leu-Pheinduced $\mathrm{O}_{2}$ consumption (see Figs 1 and 3).

As the radical-scavenging properties of sydnonimines are unlikely to account for their inhibitory effects on the respiratory burst, we studied their effects on various steps of the signal transduction cascade in human myeloid cells. Sydnonimines specifically interfered with the chemoattractantmediated activation of NADPH oxidase (see Figs 13 and Table 1). Unlike for $\mathrm{Bt}_{2} \mathrm{cAMP}$ and $\mathrm{Bt}_{2} \mathrm{cGMP}$, inhibition of agonist binding to formyl peptide receptors does not contribute to the inhibitory effects of sydnonimines on the respiratory burst as they slightly enhanced binding (see Table 2 ). Interestingly, interference of $\mathrm{Bt}_{2} \mathrm{cGMP}$ with agonist binding was also reported for other peptide receptors [36]. As sydnonimines inhibited the fMet-Leu-Phe- and C5ainduced respiratory bursts to similar extents and as receptors for these agonists couple to G-proteins, we asked the question as to whether sydnonimines could have acted at the level of G-proteins. This is, however, unlikely as they did not inhibit GTP hydrolysis of G-proteins (see Table 2). Additionally, the lack of effect of sydnonimines on potentiation by guanosine $5^{\prime}-\mathrm{O}$-(3-thiotriphosphate) of $\mathrm{O}_{2}^{-}$ formation in a cell-free system from HL-60 cells argues against interference of SIN-10 and SIN-1 with G-proteins and/or low molecular mass GTP-binding proteins. Furthermore, the resistance to inhibition by sydnonimines of the PMA-induced respiratory burst suggests that they did not inhibit protein kinase C (see Table 1). Moreover, the lack of effect of sydnonimines on arachidonic acid-induced $\mathrm{O}_{2}^{-}$ formation in a cell-free system from HL-60 cells argues against interference of these substances with a structural component of NADPH oxidase. Finally, SIN-1 and SNP effectively stimulated ADPribosylation of a $39-\mathrm{kDa}$ protein in cytosol of $\mathrm{HL}$ 60 cells, but SIN-10 did not (see Fig. 4). This finding is in agreement with the notion that ADP-ribosylation of the $39-\mathrm{kDa}$ protein depends on NO release $[14,15]$. Thus, the dissociation of the effects of sydnonimines on the fMet-Leu-Phe-induced respiratory burst on one hand and on ADPribosylation of this protein on the other suggests that covalent modification of the $39-\mathrm{kDa}$ substrate is unrelated to their inhibitory effects on $\mathrm{O}_{2}^{-}$ formation and $\mathrm{O}_{2}$ consumption (see Figs 1-4 and Table 1).

SIN-1 is known to inhibit osteoclast functions in a cGMP-independent manner, but the effects of SIN-10 were not studied [18]. Recently, Bohn et al. [23] reported NO-independent effects of an analogue of SIN-10 on vasodilation and suggested that sydnonimines may interfere with $\mathrm{Ca}^{2+}$ influx. Therefore, the effects of sydnonimines on fMet-LeuPhe-induced rises in $\left[\mathrm{Ca}^{2+}\right]_{i}$ in neutrophils were studied. Recently, we reported that SIN-1 up to $0.1 \mathrm{mmol} / \mathrm{L}$ did not inhibit fMet-Leu-Phe-induced rises in $\left[\mathrm{Ca}^{2+}\right]_{i}$, but the effects of SIN-1 at higher concentrations could not be studied for methodological reasons [7]. In this study, we show that SIN-10 at concentrations as low as $10 \mu \mathrm{mol} / \mathrm{L}$ substantially inhibited rises in $\left[\mathrm{Ca}^{2+}\right]_{\mathrm{i}}$ induced by fMet-Leu-Phe at a submaximally and maximally effective concentration (see Table 3 ). Thus, inhibition of rises in $\left[\mathrm{Ca}^{2+}\right]_{i}$ may explain, at least in part, the inhibitory effects of SIN-10 on the chemoattractantinduced respiratory burst. This notion is supported by the finding that the sydnonimines did not inhibit the PMA-induced respiratory burst, a process which is independent of rises in $\left[\mathrm{Ca}^{2+}\right]_{\mathrm{i}}$ (see Table 1) $[1,2,4]$. Also in line with our findings are data showing that SIN-10 $(10 \mu \mathrm{mol} / \mathrm{L})$ effectively inhibits thrombin-induced rises in $\left[\mathrm{Ca}^{2+}\right]_{\mathrm{i}}$ in human platelets [34]. Undoubtedly, the concentrations of SIN-10 required to inhibit the chemoattractant-induced respiratory burst are rather high (see Figs 1-3 and Table 1). However, there is ample evidence for the assumption that regulation of the respiratory burst in vitro and in vivo is quite different (for review see Ref. 2). Thus, it cannot be ruled out that the effects of sydnonimines are of clinical relevance. Similarly, the clinical importance of the effects of SIN-10 on other cell functions is not yet known $[5,7,23,34]$.

In conclusion, SIN-10 effectively inhibits the chemoattractant-induced respiratory burst in human neutrophils via a mechanism which is independent of NO release. Our present results are in accordance with other recent reports on NO-independent effects of sydnonimines $[5,7,23,34]$. Thus, future studies dealing with the pharmacological effects of SIN-1 should include experiments with the so-called "prodrug" SIN-10. This sydnonimine is not inert but may modulate various cell functions even more effectively than its so-called "active metabolite", SIN-1.

Acknowledgements-The authors are grateful to Drs E. Böhme, B. Mayer, H. H. H. W. Schmidt and G. Schultz for helpful discussion, to E. Glaß and R. Bonnet for expert technical assistance and to Dr E. Keller, Blutbank des Deutsches Rotes Kreuzes Berlin, for supplying buffy coat. This work was supported by grants of the Deutsche Forschungsgemeinschaft.

\section{REFERENCES}

1. Rossi, The $\mathrm{O}_{2}^{-}$-forming NADPH oxidase of the phagocytes: nature, mechanism of activation and function. Biochim Biophys Acta 853: 65-89, 1986.

2. Seifert $R$ and Schultz $G$, The superoxide-forming NADPH oxidase of phagocytes: an enzyme system regulated by multiple mechanisms. Rev Physiol Biochem Pharmacul 117: 1-334, 1991.

3. Absolom DR, Basic methods for the study of phagocytosis. Methods Enzymol 132: 95-180, 1986.

4. Sandborg RR and Smolen JF, Biology of disease: early biochemical events in leukocyte activation. Lab lnvest 59: $300-320,1988$

5. Schröder H, Ney P, Woditsch I Schrör K, Cyclic 
GMP mediates SIN-1-induced inhibition of human polymorphonuclear leukocytes. Eur J Pharmacol 182: 211-218, 1990.

6. Ervens J, Schultz G and Seifert R, Differential inhibition and potentiation of chemoattractant-induced superoxide formation in human neutrophils by the cellpermeant analogue of cyclic GMP, $N^{2}, 2^{\prime}$ - $O$-dibutyryl guanosine 3':5'-cyclic monophosphate. Naunyn Schmiedbergs Arch Pharmacol 343: 370-376, 1991.

7. Wenzel-Seifert K, Ervens J and Seifert R, Differential inhibition and potentiation by cell-permeant analogues of cyclic AMP and cyclic GMP and NO-containing compounds of exocytosis in human neutrophils. Naunyn Schmiedebergs Arch Pharmacol 344: 396-402, 1991.

8. Lad PM, Glovsky MM, Richards JH, Smiley PA and Backstrom B, Regulation of human neutrophil guanylate cyclase by metal ions, free radicals and the muscarinic cholinergic receptor. Mol Immunol 22: 731$739,1985$.

9. Pryzwansky KB, Wyatt TA, Nichols $H$ and Lincoln TM, Compartmentalization of cyclic GMP-dependent protein kinase in formyl-peptide stimulated neutrophils. Blood 76: 612-618, 1990.

10. Wright CD, Kuipers PJ, Kobylarz-Singer D, Devall LJ, Klinkefus BA and Weishaar RE, Differential inhibition of human neutrophil functions. Role of cyclic AMP-specific, cyclic GMP-insensitive phosphodiesterase. Biochem Pharmacol 40: 699-707, 1990.

11. Böhme E, Graf H and Schultz G, Effects of sodium nitroprusside and other smooth muscle relaxants on cyclic GMP formation in smooth muscle and platelets. Adv Cyclic Nucleotide Res 9: 131-143, 1978.

12. Böhme E, Grossmann G and Spies C, Effects of molsidomine and other NO-containing vasodilators on cyclic GMP formation. Eur Heart $J \mathbf{4}$ (Suppl C): 1924, 1983.

13. Feelisch $M$ and Noack EA, Correlation between nitric oxide formation during degradation of organic nitrates and activation of guanylate cyclase. Eur $J$ Pharmacol 139: $19-30,1987$

14. Brüne B and Lapetina EG, Activation of a cytosolic ADP-ribosyltransferase by nitric oxide-generating agents. J Biol Chem 264: 8455-8458, 1989.

15. Dimmeler $D$ and Brüne $B$, L-arginine stimulates an endogenous ADP-ribosyl-transferase. Biochem Biophys Res Commun 178: 848-855, 1991.

16. Garg UC and Hassid A, Nitric oxide-generating vasodilators inhibit mitogenesis and proliferation of BALB/C 3T3 fibroblasts by a cyclic GMP-independent mechanism. Biochem Biophys Res Commun 171: 474$479,1990$.

17. Garg UC and Hassid A, Nitric oxide decreases cytosolic free calcium in Balb/c 3T3 fibroblasts by a cyclic GMPindependent mechanism. J Biol Chem 266: 9-12, 1991.

18. MacIntyre I, Zaidi M, Alam ASMT, Datta HK, Moonga BS, Lidbury PS, Hecker M and Vane JR, Osteoclastic inhibition: an action of nitric oxide not mediated by cyclic GMP. Proc Natl Acad Sci USA 88: 2936-2940, 1991.

19. Schmidt HHHW, Seifert R and Böhme E, Formation and release of nitric oxide from human neutrophils and HL-60 cells induced by a chemotactic peptide, platelet activating factor and leukotriene $B_{4}$. FEBS Lett 244: $357-360,1989$.

20. Wright $C D$, Mülsch $A$, Busse $R$ and Osswald $H$, Generation of nitric oxide by human neutrophils. Biochem Biophys Res Commun 160: 813-819, 1989.

21. Moncada S, Palmer RMJ and Higgs EA, Biosynthesis of nitric oxide from L-arginine. A pathway for the regulation of cell function and communication. Biochem Pharmacol 38: 1709-1715, 1989.
22. Feelisch M, Ostrowski J and Noack E, On the mechanism of NO release from sydnonimimes. $J$ Cardiovasc Pharmacol 14 (Suppl 11): S13-S22, 1989.

23. Bohn H, Beyerle R, Martorana PA and Schönafinger $K$, CAS 936, a novel sydnonimine with direct vasodilating and nitric oxide-donating properties: effects on isolated blood vessels. $J$ Cardiovasc Pharmacol 18: 522-527, 1991.

24. Seifert R, Burde and Schultz G, Lack of effect of opioid peptides, morphine and naloxone on superoxide formation in human neutrophils and HL-60 leukemic cells. Naunyn Schmiedebergs Arch Pharmacol 340: 101-106, 1989.

25. Seifert $R$ and Schultz $G$, Reversible activation of NADPH oxidase in membranes of HL-60 human leukemic cells. Biochem Biophys Res Commun 146: 1296-1302, 1987

26. Wenzel-Seifert $K$, Grünbaum $L$ and Seifert $R$, Differential inhibition of human neutrophil activation by cyclosporins $\mathrm{A}, \mathrm{D}$ and $\mathrm{H}$ : cyclosporin is a potent and effective inhibitor of formyl peptide-induced superoxide formation. I Immunol 147: 1940-1946, 1991.

27. Sēifert R, Serke S, Huhn D, Bessler WG, Hauschildt S, Metzger J, Wiesmüller K-H and Jung G, Incomplete functional differentiation of HL-60 leukemic cells by synthetic lipopeptides: partial inhibition by pertussis toxin of enhanced superoxide formation. EurJ Biochem 203: 143-151, 1992.

28. Rosenthal W, Koseling D, Rudolph U, Kleuss C, Pallast $M$, Yajima $M$ and Schultz $G$, Identification and characterization of the $35-\mathrm{kDa} \beta$ subunit of guaninenucleotide-binding proteins by an antiserum raised against transducin. Eur J Biochem 158: 255-263, 1986.

29. Crapo JD, McCord JM and Fridovich I, Preparation and assay of superoxide dismutases. Methods Enzymol 53: 382-393, 1978.

30. Marklund $S$ and Marklund G, Involvement of the superoxide anion radical in the autoxidation of pyrogallol and a convenient assay for superoxide dismutase. Eur J Biochem 47: 469-474, 1974.

31. Lowry OH, Rosebrough NJ, Farr AL and Randall RJ, Protein measurement with the Folin phenol reagent. $J$ Biol Chem 193: 265-275, 1951.

32. Johnson RA and Walseth TF, The enzymatic preparation of $\left[\alpha^{-32} \mathrm{P}\right] \mathrm{ATP},\left[\alpha_{-}{ }^{32} \mathrm{P}\right] \mathrm{GTP},\left[{ }^{32} \mathrm{P}\right] \mathrm{cAMP}$, and $\left[{ }^{32} \mathrm{P}\right] \mathrm{cGMP}$, and their use in the assay of adenylate and guanylate cyclases and cyclic nucleotide phosphodiesterases. Adv Cyclic Nucleotide Res 10: $135-167,1979$.

33. Cassel D and Pfeuffer T, Mechanism of cholera toxin action: covalent modification of the guanyl nucleotidebinding protein of the adenylate cyclase system. Proc Natl Acad Sci USA 75: 2669-2673, 1978.

34. Baumann I and Baumann J, Molsidomine, the novel sydnonimine CAS 936 and their metabolites inhibit intracellular free calcium in stimulated human platelets. Naunyn Schmiedebergs Arch Pharmacol 345 (Suppl): R56, 1992.

35. Rubanyi GM, Ho FH, Cantor EH, Lumma WC and Botelho LHP, Cytoprotective function of nitric oxide: inactivation of superoxide radicals produced by human leukocytes. Biochem Biophys Res Commun 181: 1392$1397,1991$.

36. Robberecht $P$, Deschodt-Lanckman M, Woussen-Colle M-C, de Neef P, Camus JC and Christophe J, Butyryl derivatives of cyclic GMP interferc with the biological and the immunological properties of the pancreozymingastrin family of peptides. Mol Pharmacol 17: 268274, 1980. 